Brit. J. industr. Med., 1961, 18, 270.

\title{
RHEUMATISM IN COTTON OPERATIVES
}

\author{
BY \\ J. S. LAWRENCE \\ From The Empire Rheumatism Council Field Unit, University of Manchester
}

(RECEIVED FOR PUBLICATION FEBRUARY 13, 1961)

Sixty-nine male and 103 female workers aged 45 and over in a cotton spinning mill in Bolton, Lancashire were examined clinically for rheumatic disease and had radiographs taken of the hands and feet and of the cervical, dorsal, and lumbar spine. To these were added the male and female cotton workers aged 45 and over from a random sample of the population of Leigh, giving a total of 117 males and 228 females. They were compared with a control group of 117 males and 228 females from random samples in Leigh and Wensleydale who had never worked in a cotton mill. These were matched by age and sex.

Rheumatic symptoms as a whole were less frequent in the cotton workers than in the controls and loss of work from rheumatic complaints was less frequent in the male cotton workers than in the male controls. Dorsal and chest pain were more common and caused more incapacity in both male and female cotton workers than in controls.

Heberden's nodes were present in $38 \%$ of male and $35 \%$ of female cotton workers compared with $12 \%$ and $22 \%$ respectively in the controls.

Radiological evidence of osteo-arthrosis was more frequent in the distal and proximal interphalangeal joints of the fingers and in the first carpo-metacarpal joints in the male cotton workers than in the controls. In the metacarpo-phalangeal joints of the fingers, the male cotton workers had much the same prevalence of osteo-arthrosis as the controls but it was more severe. The female cotton workers showed the same osteo-arthrosis joint pattern as the males and had similar prevalences in each joint, but did not differ substantially from the female controls.

There was no significant difference between the cotton workers and controls in respect of disk degeneration of the cervical spine, but in the dorsal and lumbar spine there was less disk degeneration in the cotton workers, the difference being greater in the females.

In a survey of osteo-arthrosis and disk degeneration in the town of Leigh in Lancashire, male cotton workers were found to have more osteo-arthrosis in the finger joints and in the first carpo-metacarpal joints of the hands than the remainder of the population. The numbers examined were small and the differences, for the most part, were not significant (Kellgren and Lawrence, 1958). It was therefore decided to supplement these findings by a survey of the workers in a cotton mill in the South Lancashire area.

\section{Method}

Before choosing a mill, data on age and sex distribution and sickness records were studied for 29 mills on which such information was available. Of these, Mill A in Bolton, Lancashire, was found to have sickness absence rates which fell nearest to the average for all mills in the group and was therefore chosen. Data on sickness absence are shown in Table 1. The greater absenteeism in cardroom workers and ring spinners may be due to the fact that they are females.

\section{TABLE 1}

AVERAGE SICKNESS ABSENTEEISM, IN DAYS PER EMPLOYEE, FOR 12 MONTHS ENDED MARCH 1957

\begin{tabular}{|c|c|c|c|c|}
\hline & Cardroom & $\begin{array}{c}\text { Mule } \\
\text { Spınning }\end{array}$ & $\underset{\text { Spinning }}{\text { Ring }}$ & Doubling \\
\hline $\begin{array}{l}\text { All mills } \\
\text { Mill A }\end{array}$ & $\begin{array}{l}7.5 \\
8.0\end{array}$ & $\begin{array}{l}5.6 \\
5.2\end{array}$ & $\begin{array}{l}8.9 \\
9.7\end{array}$ & $\begin{array}{l}5 \cdot 0 \\
5 \cdot 1\end{array}$ \\
\hline
\end{tabular}

Following an initial approach to the management and to the trade union representatives at Mill A, all employees aged 45 and over were asked to come for examination to an $x$-ray van which was parked for the purpose in the mill yard. Employees who were 
TABLE 2

COMPLETION RATE

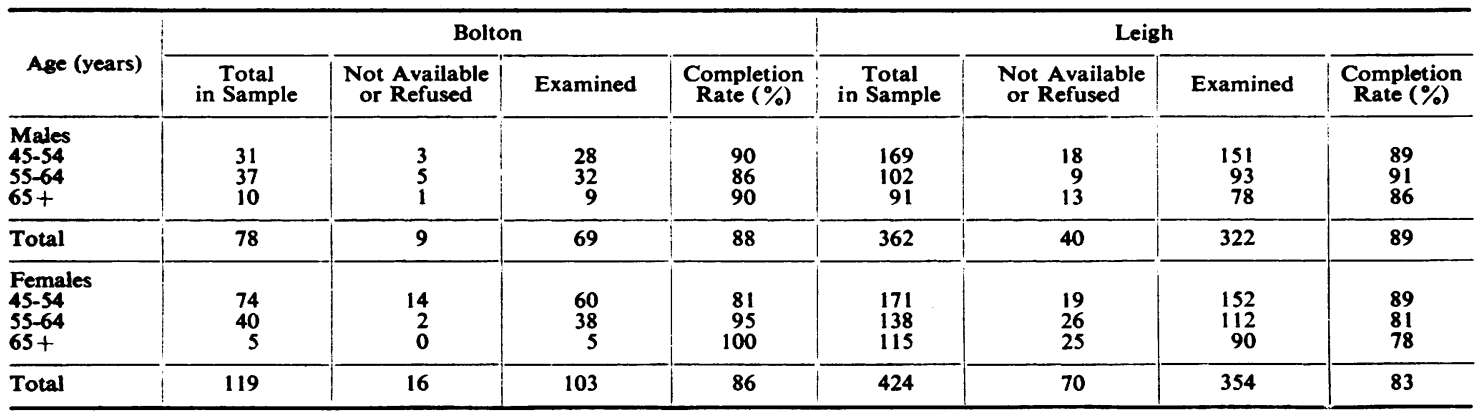

TABLE 3

OCCUPATIONAL SUB-DIVISIONS IN LEIGH AND BOLTON COTTON WORKERS AGED 45 AND OVER

\begin{tabular}{|c|c|c|c|c|c|c|c|c|c|c|}
\hline \multirow{3}{*}{ Occupation } & \multicolumn{5}{|c|}{ Males } & \multicolumn{5}{|c|}{ Females } \\
\hline & \multicolumn{5}{|c|}{ Age (years) } & \multicolumn{5}{|c|}{ Age (years) } \\
\hline & Total & $45-54$ & -64 & -74 & $75+$ & Total & $45-54$ & -64 & -74 & $75+$ \\
\hline $\begin{array}{l}\text { Weavers } \\
\text { Spinners and doublers } \\
\text { Tenters and others }\end{array}$ & $\begin{array}{r}2 \\
81 \\
34\end{array}$ & $\begin{array}{r}2 \\
35 \\
12\end{array}$ & $\begin{array}{r}0 \\
30 \\
19\end{array}$ & $\begin{array}{r}0 \\
14 \\
3\end{array}$ & $\begin{array}{l}\mathbf{0} \\
\mathbf{2} \\
\mathbf{0}\end{array}$ & $\begin{array}{l}66 \\
69 \\
93\end{array}$ & $\begin{array}{l}26 \\
45 \\
52\end{array}$ & $\begin{array}{l}30 \\
23 \\
35\end{array}$ & $\begin{array}{l}7 \\
1 \\
4\end{array}$ & $\begin{array}{l}\mathbf{3} \\
\mathbf{0} \\
\mathbf{2}\end{array}$ \\
\hline Total & 117 & 49 & 49 & 17 & 2 & 228 & 123 & 88 & 12 & 5 \\
\hline
\end{tabular}

not actually working with cotton, such as administrative and clerical staff, were excluded. A clinical examination was made of the musculo-skeletal system and routine radiographs were taken of the hands and feet and of the cervical, dorsal, and lumbar spine. Employees who were unwilling to come to the $x$-ray van, were examined in an office in the mill and had radiographs of hands, feet, and neck taken with a portable $x$-ray apparatus. Those who were absent on sick leave were either asked to come to the $x$-ray van, or had radiographs taken at their homes.

Altogether 69 males and 103 females were examined (Table 2) out of a total of 78 males and 119 females of appropriate age. This gave a completion rate of $88 \%$ in males and $86 \%$ in females. Only in the females aged 45-54 did the completion rate fall below $85 \%$. Similar rates had been achieved in the random samples of the populations of Leigh and Wensleydale from which the control group was taken. The control group was chosen from those in the random sample who had never worked in a cotton mill and who had radiographs taken of hands, feet, cervical and lumbar, and (where available) dorsal spine. Radiographs of these sites were taken as a routine in the second half of the Leigh survey which took place in 1957. The 55-64 age group, however, had radiographs taken in a separate survey in 1954 and no radiographs of the dorsal spine were obtained. To fill this gap, a second sample aged 55-64 was examined in 1957 and radiographs of the dorsal spine only were taken. A matched sample of these has been used as controls in the data on dorsal disk degeneration. The predominant occupations of the controls were coal-mining in males and domestic in females.

For the purposes of this study, all those aged 45 and over in the Leigh random sample whose predominant occupation had been in the cotton mills were added to the Mill A cotton workers. This gave a total of 117 males and 228 females (Table 3). The largest proportion was in the 45-54 age group in the females but was equally distributed between this and the 55-64 age group in males. The cotton workers were divided into three groups according to their occupation in the mills. Spinning was the most frequent occupation in males but in females the occupations were fairly evenly distributed between weavers, spinners, and tenters (machine tenders), the last being the largest. This was a miscellaneous group comprising mainly cardroom workers.

\section{Clinical Features}

Altogether $85(73 \%)$ of the 117 male cotton workers gave a history of rheumatic symptoms, com- 
pared with $104(89 \%)$ of the controls (Table 4). Loss of work from rheumatism had occurred in $39(34 \%)$ of the male cotton workers and $57(49 \%)$ of the controls. Only in the dorsal region was there a substantially greater prevalence of symptoms in the male cotton workers. This was associated with either no loss of work or loss of less than three months in all instances in the cotton workers.

In the females similarly (Table 5) there were in general fewer rheumatic complaints in the cotton workers ( $74 \%$ compared with $85 \%$ in the controls). There was however, no significant difference in incapacity; $32 \%$ of cotton workers lost work from rheumatism, compared with $28 \%$ of the controls. The dorsal spine was the only area in which symptoms were more frequent in female cotton workers and this area and the cervical spine were mainly responsible for the slightly greater incapacity in these workers.

Altogether 63 of the male controls had worked in coal-mines. When these were excluded, the symptom rate in the controls was still slightly greater than in the cotton workers.

Physical Signs.-The only striking feature on clinical examination of the cotton workers was the frequency of Heberden's nodes which were present in $38 \%$ of males and $35 \%$ of females, and in $12 \%$ and $22 \%$ of the controls.

\section{Radiological Findings}

The radiographs of the cotton workers and controls were mixed together before reading so that the observer was unaware of their source. They were

TABLE 4

RHEUMATIC COMPLAINTS AND LOSS OF WORK IN 117 MALE COTTON WORKERS AND CONTROLS

\begin{tabular}{|c|c|c|c|c|c|c|}
\hline \multirow{3}{*}{ Site of Pain } & \multirow{3}{*}{$\begin{array}{c}\text { Number } \\
\text { With } \\
\text { Pain }\end{array}$} & \multicolumn{2}{|c|}{ Cotton Workers } & \multirow{3}{*}{$\begin{array}{c}\text { Number } \\
\text { With } \\
\text { Pain }\end{array}$} & \multicolumn{2}{|c|}{ Controls } \\
\hline & & \multicolumn{2}{|c|}{ Number Off Work } & & \multicolumn{2}{|c|}{ Number Off Work } \\
\hline & & 1-11 Weeks & 3 Months & & 1-11 Weeks & 3 Months + \\
\hline $\begin{array}{l}\text { Distal interphalangeal joints } \\
\text { Proximal interphalangeal joints } \\
\text { Metacarpo-phalangeal joints } \\
\text { Carpo-metacarpal joints } \\
\text { Wrists } \\
\text { Cervical spine } \\
\text { Dorsal spine } \\
\text { Lumbar spine } \\
\text { Hips } \\
\text { Sacro-iliac joints } \\
\text { Knees } \\
\text { Tarsi } \\
\text { Lateral metatarso-phalangeal joints } \\
\text { First metatarso-phalangeal joints }\end{array}$ & $\begin{array}{r}7 \\
14 \\
9 \\
6 \\
6 \\
34 \\
19 \\
43 \\
4 \\
3 \\
28 \\
15 \\
6 \\
8\end{array}$ & $\begin{array}{r}1 \\
2 \\
1 \\
1 \\
1 \\
5 \\
6 \\
19 \\
0 \\
0 \\
4 \\
3 \\
1 \\
1\end{array}$ & $\begin{array}{l}2 \\
2 \\
2 \\
2 \\
2 \\
2 \\
2 \\
0 \\
5 \\
2 \\
2 \\
4 \\
3 \\
2 \\
2\end{array}$ & $\begin{array}{r}8 \\
12 \\
7 \\
4 \\
11 \\
48 \\
8 \\
59 \\
12 \\
5 \\
41 \\
12 \\
8 \\
12\end{array}$ & $\begin{array}{r}\mathbf{0} \\
\mathbf{0} \\
\mathbf{0} \\
\mathbf{0} \\
1 \\
12 \\
\mathbf{1 2} \\
\mathbf{1 6} \\
\mathbf{2} \\
\mathbf{2} \\
\mathbf{5} \\
1 \\
\mathbf{0} \\
1\end{array}$ & $\begin{array}{r}4 \\
4 \\
4 \\
3 \\
4 \\
4 \\
1 \\
11 \\
3 \\
1 \\
10 \\
4 \\
4 \\
4\end{array}$ \\
\hline No. of workers and controls affected & $85(73 \%)$ & $30(26 \%)$ & $9(8 \%)$ & $104(89 \%)$ & $34(29 \%)$ & $23(20 \%)$ \\
\hline
\end{tabular}

TABLE 5

RHEUMATIC COMPLAINTS AND LOSS OF WORK IN 228 FEMALE COTTON WORKERS AND CONTROLS

\begin{tabular}{|c|c|c|c|c|c|c|}
\hline \multirow{3}{*}{ Site of Pain } & \multicolumn{3}{|c|}{ Cotton Workers } & \multicolumn{3}{|c|}{ Controls } \\
\hline & \multirow{2}{*}{$\begin{array}{c}\text { Number } \\
\text { With } \\
\text { Pain }\end{array}$} & \multicolumn{2}{|c|}{ Number Off Work } & \multirow{2}{*}{$\begin{array}{c}\text { Number } \\
\text { With } \\
\text { Pain }\end{array}$} & \multicolumn{2}{|c|}{ Number Off Work } \\
\hline & & 1-11 Weeks & 3 Months & & 1-11 Weeks & 3 Months + \\
\hline $\begin{array}{l}\text { Distal interphalangeal joints } \\
\text { Proximal interphalangeal joints } \\
\text { Metacarpo-phalangeal joints } \\
\text { Carpo-metacarpal joints } \\
\text { Wrists } \\
\text { Cervical spine } \\
\text { Dorsal spine } \\
\text { Lumbar spine } \\
\text { Hips } \\
\text { Sacro-iliac joints } \\
\text { Knees } \\
\text { Tarsi } \\
\text { Lateral metatarso-phalangeal joints } \\
\text { First metatarso-phalangeal joints }\end{array}$ & $\begin{array}{r}28 \\
35 \\
32 \\
32 \\
19 \\
88 \\
27 \\
81 \\
8 \\
7 \\
56 \\
39 \\
19 \\
26\end{array}$ & $\begin{array}{r}4 \\
4 \\
4 \\
2 \\
6 \\
17 \\
8 \\
25 \\
0 \\
0 \\
8 \\
11 \\
0 \\
3\end{array}$ & $\begin{array}{r}5 \\
6 \\
7 \\
9 \\
4 \\
7 \\
3 \\
9 \\
3 \\
3 \\
8 \\
10 \\
5 \\
7\end{array}$ & $\begin{array}{r}44 \\
55 \\
53 \\
39 \\
40 \\
103 \\
23 \\
103 \\
20 \\
11 \\
93 \\
57 \\
33 \\
35\end{array}$ & $\begin{array}{r}6 \\
6 \\
6 \\
6 \\
6 \\
12 \\
2 \\
28 \\
2 \\
3 \\
15 \\
9 \\
5 \\
5\end{array}$ & $\begin{array}{r}11 \\
12 \\
12 \\
11 \\
10 \\
7 \\
2 \\
6 \\
7 \\
5 \\
23 \\
12 \\
10 \\
9\end{array}$ \\
\hline Pain at all sites & $177(74 \%)$ & $51(21 \%)$ & $27(11 \%)$ & $195(85 \%)$ & $40(18 \%)$ & $21(10 \%)$ \\
\hline
\end{tabular}




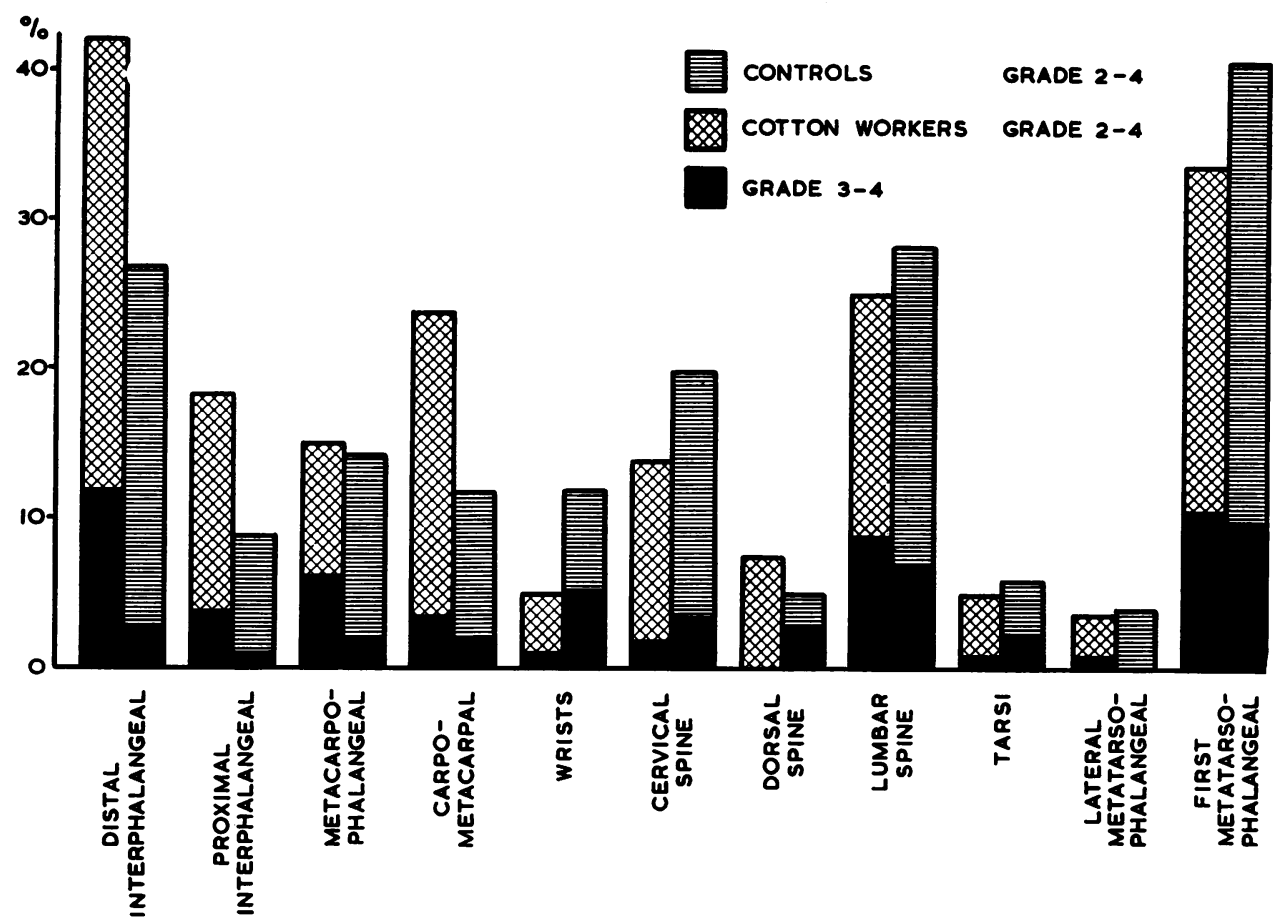

Fig. 1.-Osteo-arthrosis in male cotton workers and controls.

graded for osteo-arthrosis and rheumatoid arthritis and in the spine films for disk degeneration. Each diagnosis was graded 0-4 for each type of joint, using standard films (Kellgren and Lawrence, 1957; Lawrence and Bremner, 1961).

Osteo-arthrosis. - Radiological evidence of osteoarthrosis was found to be more common in male cotton workers than controls in four types of joint and less common in seven (Fig. 1). The joints which were more affected in the cotton workers were all in the hands and included the distal and proximal interphalangeal, the metacarpo-phalangeal and first carpo-metacarpal joints. There was no difference in the frequency and severity of these changes between the right and left hands. Only in the wrists was there appreciably more osteo-arthrosis in the controls $\left(\chi^{2}=3 \cdot 2, p=0 \cdot 08\right)$. The difference between grade

TABLE 6

OSTEO-ARTHROSIS JOINT PATTERN IN FEMALE COTTON WORKERS AND CONTROLS

\begin{tabular}{|c|c|c|c|c|c|c|c|c|c|c|c|c|c|c|c|c|}
\hline & \multicolumn{8}{|c|}{ Cotton Workers } & \multicolumn{8}{|c|}{ Controls } \\
\hline & \multirow{2}{*}{$\begin{array}{l}\text { Number } \\
\text { Ra dio- } \\
\text { graphed }\end{array}$} & \multicolumn{7}{|c|}{ Grade } & \multirow{2}{*}{$\begin{array}{c}\text { Number } \\
\text { Radio- } \\
\text { graphed }\end{array}$} & \multicolumn{7}{|c|}{ Grade } \\
\hline & & $\mathbf{0}$ & 1 & 2 & 3 & 4 & $\begin{array}{l}2-4 \\
(\%)\end{array}$ & $\begin{array}{l}3-4 \\
(\%)\end{array}$ & & 0 & 1 & 2 & 3 & 4 & $\begin{array}{l}2-4 \\
(\%)\end{array}$ & $\begin{array}{l}3-4 \\
(\%)\end{array}$ \\
\hline $\begin{array}{l}\text { Distal interphalangeal joints } \\
\text { Proximal interphalangeal joints } \\
\text { Metacarpo-phalangeal joints } \\
\text { Carpo-metacarpal joints } \\
\text { Wrists } \\
\text { Cervical spine } \\
\text { Dorsal spine } \\
\text { Lumbar spine } \\
\text { Tarsi } \\
\text { Lateral metatarso-phalangeal joints } \\
\text { First metatarso-phalangeal joints }\end{array}$ & $\begin{array}{l}225 \\
225 \\
225 \\
225 \\
225 \\
222 \\
128 \\
200 \\
222 \\
222 \\
222\end{array}$ & $\begin{array}{r}72 \\
145 \\
155 \\
137 \\
195 \\
153 \\
88 \\
83 \\
189 \\
193 \\
80\end{array}$ & $\begin{array}{l}49 \\
30 \\
46 \\
37 \\
18 \\
45 \\
31 \\
77 \\
23 \\
17 \\
51\end{array}$ & $\begin{array}{r}79 \\
38 \\
21 \\
31 \\
8 \\
20 \\
9 \\
32 \\
3 \\
11 \\
68\end{array}$ & $\begin{array}{r}17 \\
10 \\
2 \\
14 \\
4 \\
3 \\
0 \\
7 \\
7 \\
1 \\
1\end{array}$ & $\begin{array}{l}8 \\
2 \\
1 \\
6 \\
0 \\
1 \\
1 \\
0 \\
1 \\
0 \\
0 \\
3\end{array}$ & $\begin{array}{r}46 \\
22 \\
11 \\
23 \\
5 \\
11 \\
7 \\
20 \\
5 \\
5 \\
41\end{array}$ & $\begin{array}{r}11 \\
5 \\
1 \\
9 \\
2 \\
2 \\
0 \\
4 \\
3 \\
0.4 \\
10\end{array}$ & $\begin{array}{c}226 \\
226 \\
226 \\
226 \\
225 \\
223 \\
41 * \\
214 \\
224 \\
225 \\
224\end{array}$ & $\begin{array}{r}108 \\
159 \\
163 \\
159 \\
205 \\
139 \\
23 \\
84 \\
198 \\
203 \\
111\end{array}$ & $\begin{array}{l}30 \\
28 \\
34 \\
29 \\
12 \\
51 \\
11 \\
93 \\
14 \\
14 \\
41\end{array}$ & $\begin{array}{r}66 \\
28 \\
24 \\
25 \\
8 \\
26 \\
7 \\
30 \\
8 \\
5 \\
54\end{array}$ & $\begin{array}{r}15 \\
7 \\
4 \\
11 \\
0 \\
6 \\
0 \\
3 \\
4 \\
1 \\
14\end{array}$ & $\begin{array}{l}7 \\
4 \\
1 \\
2 \\
0 \\
1 \\
0 \\
4 \\
0 \\
2 \\
4\end{array}$ & $\begin{array}{r}39 \\
17 \\
13 \\
17 \\
6 \\
15 \\
17 \\
17 \\
5 \\
4 \\
32\end{array}$ & $\begin{array}{r}10 \\
5 \\
2 \\
6 \\
0 \\
3 \\
0 \\
3 \\
2 \\
1 \\
8\end{array}$ \\
\hline
\end{tabular}

- The control group of dorsal spine radiographs in the 55-64 age group were drawn from a special sample radiographed in 1957. 


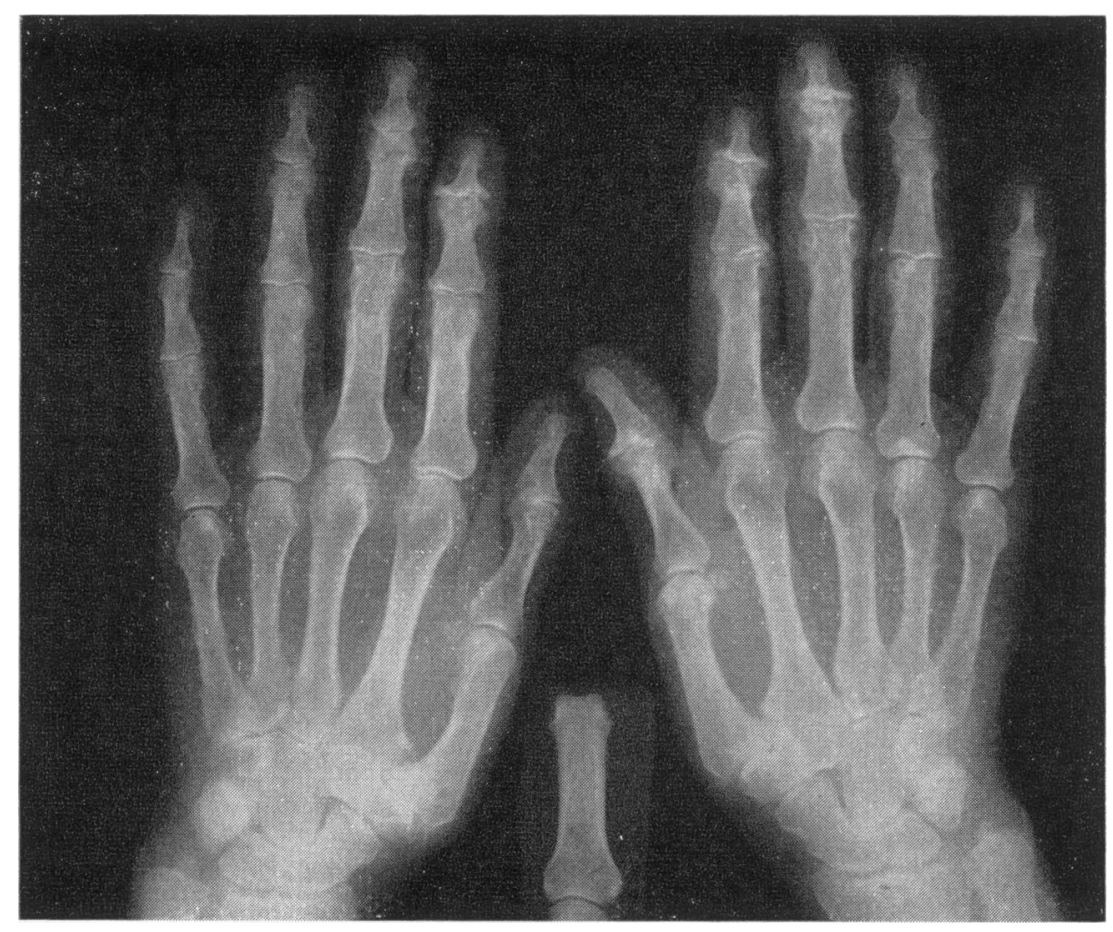

Fig. 2.-Radiograph of hand of male cotton operative.

3-4 osteo-arthrosis in the distal interphalangeal joints in cotton workers and that in controls was highly significant $\left(\chi^{2}=7 \cdot 2, p=<0 \cdot 01\right)$.

In females the pattern of osteo-arthrosis and the general prevalence in cotton workers were very similar to those in the controls (Table 6). This was largely a result of the high prevalence in the female controls who had as much osteo-arthrosis as the male cotton workers. Such differences as occurred between the female cotton workers and controls were similar to those between male cotton workers and controls but were in no instance significant (Table 7).

The radiographic changes in the hand are illustrated in Fig. 2.

Disk Degeneration.-In males the prevalence and severity of cervical disk degeneration were identical

TABLE 7

OSTEO-ARTHROSIS JOINT PATTERN IN MALE COTTON WORKERS AND CONTROLS

\begin{tabular}{|c|c|c|c|c|c|c|c|c|c|c|c|c|c|c|c|c|}
\hline & \multicolumn{8}{|c|}{ Cotton Workers } & \multicolumn{8}{|c|}{ Controls } \\
\hline & \multirow{2}{*}{$\begin{array}{l}\text { Number } \\
\text { Radio- } \\
\text { graphed }\end{array}$} & \multicolumn{7}{|c|}{ Grade } & \multirow{2}{*}{$\begin{array}{l}\text { Number } \\
\text { Radio- } \\
\text { graphed }\end{array}$} & \multicolumn{7}{|c|}{ Grade } \\
\hline & & $\mathbf{0}$ & 1 & 2 & 3 & 4 & $\begin{array}{c}2.4 \\
(\%)\end{array}$ & $\begin{array}{l}3-4 \\
(\%)\end{array}$ & & $\mathbf{0}$ & 1 & 2 & 3 & 4 & $\begin{array}{l}2-4 \\
(\%)\end{array}$ & $\begin{array}{l}3-4 \\
(\%)\end{array}$ \\
\hline $\begin{array}{l}\text { Distal interphalangeal joints } \\
\text { Proximal interphalangeal joints } \\
\text { Metacarpo-phalangeal joints } \\
\text { Carpo-metacarpal joints } \\
\text { Wrists } \\
\text { Cervical spine } \\
\text { Dorsal spine } \\
\text { Lumbar spine } \\
\text { Tarsi } \\
\text { Lateral metatarso-phalangeal joints } \\
\text { First metatarso-phalangeal joints }\end{array}$ & $\begin{array}{l}115 \\
115 \\
115 \\
115 \\
115 \\
113 \\
72 \\
103 \\
115 \\
115 \\
115\end{array}$ & $\begin{array}{r}40 \\
78 \\
83 \\
70 \\
97 \\
67 \\
52 \\
40 \\
94 \\
106 \\
58\end{array}$ & \begin{tabular}{r|r}
27 & \\
14 & \\
15 & \\
16 & \\
12 & \\
30 & \\
16 & \\
36 & \\
15 & \\
4 & \\
18 &
\end{tabular} & $\begin{array}{r}34 \\
19 \\
10 \\
25 \\
5 \\
14 \\
4 \\
18 \\
5 \\
4 \\
26\end{array}$ & $\begin{array}{r}11 \\
3 \\
5 \\
3 \\
1 \\
2 \\
0 \\
9 \\
1 \\
1 \\
13\end{array}$ & $\begin{array}{l}3 \\
1 \\
2 \\
1 \\
0 \\
0 \\
0 \\
0 \\
0 \\
0 \\
0\end{array}$ & $\begin{array}{r}42 \\
20 \\
15 \\
25 \\
5 \\
14 \\
8 \\
26 \\
5 \\
4 \\
34\end{array}$ & $\begin{array}{r}12 \\
3 \\
6 \\
3 \\
1 \\
2 \\
0 \\
9 \\
1 \\
1 \\
11\end{array}$ & $\begin{array}{c}117 \\
117 \\
117 \\
117 \\
116 \\
115 \\
60^{*} \\
102 \\
116 \\
116 \\
116\end{array}$ & $\begin{array}{r}59 \\
102 \\
88 \\
81 \\
85 \\
54 \\
37 \\
35 \\
100 \\
108 \\
48\end{array}$ & $\begin{array}{r}26 \\
4 \\
13 \\
22 \\
17 \\
38 \\
20 \\
37 \\
9 \\
3 \\
20\end{array}$ & $\begin{array}{r}29 \\
10 \\
14 \\
11 \\
8 \\
19 \\
1 \\
23 \\
4 \\
5 \\
36\end{array}$ & $\begin{array}{r}2 \\
1 \\
1 \\
3 \\
6 \\
2 \\
2 \\
7 \\
2 \\
0 \\
10\end{array}$ & $\begin{array}{l}1 \\
0 \\
1 \\
0 \\
0 \\
2 \\
0 \\
0 \\
1 \\
0 \\
2\end{array}$ & $\begin{array}{r}27 \\
9 \\
14 \\
12 \\
12 \\
20 \\
5 \\
29 \\
5 \\
4 \\
41\end{array}$ & $\begin{array}{r}3 \\
\mathbf{1} \\
\mathbf{2} \\
\mathbf{3} \\
\mathbf{5} \\
\mathbf{3} \\
\mathbf{3} \\
\mathbf{7} \\
\mathbf{3} \\
\mathbf{0} \\
\mathbf{1 0}\end{array}$ \\
\hline
\end{tabular}

*The control group of dorsal spine radiographs in the 55-64 age group were drawn from a special sample radiographed in 1957 . 
TABLE 8

DISK DEGENERATION IN COTTON WORKERS AND CONTROLS

\begin{tabular}{|c|c|c|c|c|c|c|c|c|c|c|c|c|c|c|c|c|c|c|}
\hline & \multicolumn{9}{|c|}{ Cotton Workers } & \multicolumn{9}{|c|}{ Controls } \\
\hline & \multirow{2}{*}{$\begin{array}{l}\text { Number } \\
\text { Radio- } \\
\text { graphed }\end{array}$} & \multicolumn{3}{|c|}{ Grade } & & & \multirow{2}{*}{$\begin{array}{l}\text { Four or } \\
\text { More } \\
\text { Disks } \\
\text { Affected }\end{array}$} & \multicolumn{2}{|c|}{ Grade } & \multirow{2}{*}{$\begin{array}{l}\text { Number } \\
\text { Radio- } \\
\text { graphed }\end{array}$} & \multicolumn{4}{|c|}{ Grade } & \multirow[b]{2}{*}{4} & \multirow{2}{*}{\begin{tabular}{|c} 
Four or \\
More \\
Disks \\
Affected
\end{tabular}} & \multicolumn{2}{|c|}{ Grade } \\
\hline & & 0 & 1 & 2 & 3 & 4 & & $\begin{array}{c}2-4 \\
\left(\begin{array}{c}0 \\
0\end{array}\right)\end{array}$ & $\begin{array}{c}3-4 \\
(\%)\end{array}$ & & 0 & 1 & 2 & 3 & & & $\begin{array}{l}2-4 \\
(\%)\end{array}$ & $\begin{array}{c}3-4 \\
(\%)\end{array}$ \\
\hline $\begin{array}{l}\text { Males } \\
\text { Cervical spine } \\
\text { Dorsal spine } \\
\text { Lumbar spine }\end{array}$ & $\begin{array}{r}113 \\
72 \\
103\end{array}$ & $\begin{array}{l}29 \\
16 \\
21\end{array}$ & $\begin{array}{r}5 \\
3 \\
15\end{array}$ & $\begin{array}{l}31 \\
40 \\
56\end{array}$ & $\begin{array}{r}43 \\
11 \\
9\end{array}$ & $\begin{array}{l}5 \\
2 \\
2\end{array}$ & $\begin{array}{l}12 \\
39 \\
15\end{array}$ & $\begin{array}{l}70 \\
74 \\
65\end{array}$ & $\begin{array}{l}42 \\
18 \\
10\end{array}$ & $\begin{array}{r}115 \\
60 \\
107\end{array}$ & \begin{tabular}{r|r}
19 \\
4 \\
24
\end{tabular} & $\begin{array}{r}16 \\
4 \\
7\end{array}$ & $\begin{array}{l}36 \\
35 \\
54\end{array}$ & $\begin{array}{l}36 \\
15 \\
21\end{array}$ & $\begin{array}{l}8 \\
2 \\
1\end{array}$ & $\begin{array}{l}12 \\
33 \\
32\end{array}$ & $\begin{array}{l}70 \\
86 \\
71\end{array}$ & $\begin{array}{l}38 \\
28 \\
21\end{array}$ \\
\hline $\begin{array}{l}\text { Females } \\
\text { Cervical spine } \\
\text { Dorsal spine } \\
\text { Lumbar spine }\end{array}$ & $\begin{array}{l}222 \\
128 \\
200\end{array}$ & $\begin{array}{l}86 \\
33 \\
87\end{array}$ & $\begin{array}{r}17 \\
5 \\
35\end{array}$ & $\begin{array}{l}62 \\
71 \\
67\end{array}$ & $\begin{array}{l}52 \\
18 \\
10\end{array}$ & $\begin{array}{l}5 \\
1 \\
1\end{array}$ & $\begin{array}{r}8 \\
60 \\
17\end{array}$ & $\begin{array}{l}76 \\
70 \\
39\end{array}$ & $\begin{array}{r}26 \\
15 \\
6\end{array}$ & $\begin{array}{c}223 \\
41^{*} \\
214\end{array}$ & $\begin{array}{r}68 \\
2 \\
70\end{array}$ & $\begin{array}{r}25 \\
2 \\
46\end{array}$ & $\begin{array}{l}66 \\
21 \\
69\end{array}$ & $\begin{array}{l}57 \\
15 \\
22\end{array}$ & $\begin{array}{l}7 \\
1 \\
7\end{array}$ & $\begin{array}{l}18 \\
27 \\
15\end{array}$ & $\begin{array}{l}61 \\
90 \\
46\end{array}$ & $\begin{array}{l}30 \\
39 \\
14\end{array}$ \\
\hline
\end{tabular}

*See footnote to Table 6.

in cotton workers and controls, but dorsal disk degeneration was slightly less frequent in the cotton workers, of whom $74 \%$ had definite evidence of this disease in one or more disks, compared with $86 \%$ in the controls (Table 8). Lumbar disk degeneration was also less frequent in the male cotton workers than in the controls, particularly the more severe forms.

The female cotton workers had slightly more cervical disk degeneration than the controls but of less severity, and on balance it appears there is no occupational influence. Both dorsal and lumbar disk degeneration, however, were appreciably less in the female cotton workers than in the controls. The number of female controls in whom a dorsal radiograph was available was small, as routine radiographs of this region were taken in only a third of the respondents. It is, however, clear that the greater loss of working time from dorsal symptoms in cotton workers cannot be attributed to disk degeneration, nor was any other objective cause found.

\section{Occupational Sub-divisions in Cotton Workers}

In Table 9 the cotton workers have been divided into three groups, weavers, spinners, and " others ", and the prevalence of osteo-arthrosis in the distal and proximal interphalangeal joints and the first carpo-metacarpal joints in these three groups is compared. There were insufficient male weavers for any conclusions to be reached, but the spinners and " others" may be compared. Both spinners and " others " had more osteo-arthrosis in the first carpometacarpal joints than the controls ( $c f$. Table 7), but the spinners had the greatest prevalence in these joints and also in the distal interphalangeals. In the proximal interphalangeals there was little difference. In female cotton workers there was more disease in all joints in the weavers but this group had more old people. When corrected for age, this difference largely disappeared. Between the spinners and " others ", there was also little difference, though the proximal interphalangeal joints were less affected in the spinners than in the " others".

It appears that all the main types of occupation in the cotton mill are associated with an increased prevalence of osteo-arthrosis in these three joints.

Rheumatoid arthritis was encountered in $3 \%$ of male and $7 \%$ of female cotton workers and spondylitis and gout each in $1 \%$ of male cotton workers.

TABLE 9

OSTEO-ARTHROSIS OF THE DISTAL INTERPHALANGEAL AND PROXIMAL INTERPHALANGEAL AND FIRST CARPO-METACARPAL JOINTS IN SPINNERS, WEAVERS, AND OTHERS

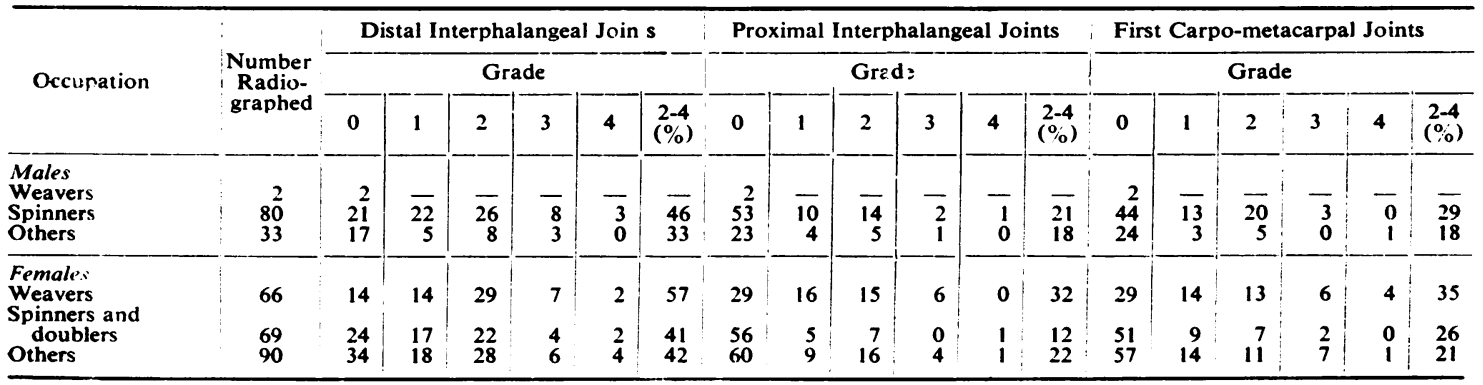


These prevalences are not significantly different from those in the general population. There is thus no evidence of an occupational factor in these diseases so far as cotton workers are concerned.

\section{Discussion}

No comparison of workers in a particular occupation with those in all remaining occupations in the area can be said to give a complete picture of the effect of occupation on disease, since occupational factors may well play a part in the control group. In the town of Leigh, from which the control group was mainly drawn, a third of the male workers were coal-miners. It is known that mining has a considerable effect on the incidence of osteoarthrosis in many joints and also on disk degeneration (Kellgren and Lawrence, 1952; Lawrence, 1955). This accounts for the higher prevalence of osteoarthrosis in the wrists in the controls and tends to hide increased prevalences in other joints in the cotton workers. It would, however, be unreasonable to remove only miners from the control group since almost all occupations probably influence osteoarthrosis to some extent.

The picture is further complicated by the influence of heredity which affects both the frequency and pattern of osteo-arthrosis. In females, Heberden's nodes together with osteo-arthrosis of the interphalangeal, metacarpo-phalangeal, and first carpometacarpal joints are greatly influenced by genetic factors (Lawrence, 1961). It is not surprising therefore, that the differences in joint pattern in females between cotton workers and controls are relatively small and insignificant.

The lower general symptom rate in cotton workers is of interest particularly as it is associated in the males with reduced loss of work from rheumatic troubles. This does not appear to be due to a reduced prevalence or severity of rheumatic disease in the cotton workers who indeed have more severe disease in certain joints. A dissociation between the radiographic changes of degenerative joint disease and symptoms has also been noted in coal-miners, those working in wet seams having more symptoms and incapacity than those in dry seams, despite identical severity of radiographic changes (Lawrence,
1955). This was attributed to a reduced pain threshold from cooling of tissues at the sites of referred pain. In cotton mills the atmosphere is humid but very warm, and this may well account for the dissociation found in these workers. It is of interest that in the weavers, who work in relatively cool conditions, symptoms were more frequent, $88 \%$ having rheumatic complaints compared with $74 \%$ in the spinners and cardroom workers and $85 \%$ in the controls. This was not associated with a reduction of loss of work from rheumatic complaints.

The increased prevalence of osteo-arthrosis observed in the finger and thumb joints in these cotton workers did not appear to be due to overt trauma since few gave a history of injury. Two factors may play a part. The skilled cotton operative is using his fingers continuously and rapidly, and the joints may be subject to continuous minor traumata, for example, knocking against frames and bobbins. Secondly he is working in a warm atmosphere with a consequent raising of his pain threshold so that the effects of slight trauma are less likely to be noticed. The combination of these two factors may well be responsible for the severe changes sometimes encountered.

In view of the relatively benign nature of the disease found in cotton operatives, preventive measures are not indicated.

I wish to express my thanks to the manager and workers in the Mill for their kind co-operation. I am indebted to Messrs. Fine Spinners and Doublers of Manchester, who not only gave permission to carry out this survey, but also supplied data on sickness absence in their mills.

I am also indebted to Professor R. E. Lane and Dr. W. R. Lee of the Department of Occupational Health, Manchester University, for their advice.

\section{REFERENCES}

Kellgren, J. H., and Lawrence, J. S. (1952). Brit. J. industr. Med., 9, 197.

(1957). Ann. rheum. Dis., 16, 494

(1958). Ann. rheum.

Lawrence, J. S. (1955). Brit. J. industr. Med., 12, 249.

- (1961). Ann. rheum. Dis., 20, 11.

-, and Bremner, J. (1961). Ibid. (in the press). 